Volume 20 Number 2 December 2020 p 334-349

https://doi.org/10.30603/au.v20i2.1396

\title{
Taboo in Banjarese Culture
}

\author{
(an Anthropological and Quranic Analysis)
}

\section{Rahmat Sholihin, Asmawan, Wahyudin, Badrian, Amelia Rahmaniah UIN Antasari Banjarmasin}

\begin{abstract}
This paper focuses on the wisdom of Banjar culture, namely pamali. The objectives of this research are first to understand the pamali culture of Banjar, and secondly to see it from the perspective of the Qur'an. The research method used is qualitative research with an anthropological approach. The research locations are in Indonesia, South Kalimantan (Banjarmasin, Martapura, and Amuntai). The findings in this study indicate that the prohibition contained in the Banjar tradition is intended to provide a gentle warning. There are several prohibitions in the Koran regarding culture: do not be disobedient to your parents, teachers, and husbands.
\end{abstract}

\section{Tabu dalam Budaya Banjar}

\section{Abstrak}

\section{(Analisis Antropologi dan Norma Qur'an)}

Paper ini fokus pada kearifan budaya Banjar yaitu pamali. Tujuan dari penelitian ini adalah: untuk memahami budaya pamali dari Banjar dan melihatnya dalam perspektif Qur'ani. Metode penelitian yang digunakan adalah penelitian kualitatif dengan pendekatan antropologi. Adapun lokasi penelitian adalah di Indonesia, Kalimantan Selatan (Banjarmasin, Martapura dan Amuntai). Temuan dalam penelitian ini menyatakan bahwa bentuk larangan yang terkandung dalam tradisi Banjar itu dimaksudkan untuk memberikan teguran secara halus. Ada beberapa larangan dalam Al-Quran sejalan dengan budaya, seperti: jangan durhaka dengan orang tua, guru dan suami.

Keywords : Tabu, Banjar Culture, Anthropology.

Author correspondence

Email: rahmatsholihin@uin-antasari.ac.id

Available online at http://journal.iaingorontalo.ac.id/index.php/au/index 


\section{A. Introduction}

The education system in Indonesia is directed towards producing creative, independent and responsible human resources that embody the concepts of Indonesian national education. ${ }^{1}$ Education system in Indonesia is very unique and interesting, besides formal education in schools there is also education informal in the family environment. Families occupy an important position to teach the good and bad traditions of the local culture. Moral teaching in the family environment has a powerful effect on children's mental development in the future. Teaching the child good is the responsibility of the parents. In addition to teaching good things to do, children are also taught bad behavior to avoid.

Taboo is not a foreign language to Indonesian people, including those of the Banjar tribe. However, over time, the existence of words, phrases, or sentences seems to have become a part of what is being interpreted and affixed to conservative labels and primitive impressions. In today's youth perspective, taboo language is more likely to be understood as a myth packed in the form of oldfashioned parental advice for something less common or unwelcome.

The debate between parents and the younger generation today about taboo language is undercut by differences in mindset. With all its facilities, the young generation can receive a wealth of knowledge and information that can trigger a series of prolonged questions that need answers. Creativity in asking questions in today's young age is so rapid that parents who struggle to use taboo words or sentences as they were in their early teens often find it difficult to answer their children's questions today. ${ }^{2}$

Some young people today think that the word tabu (pamali) is just a myth. They consider this to be the downfall of a culture because they are unable to keep

1 Abur Hamdi Usman et al., "Humanism in Islamic Education: Indonesian References," International Journal of Asia Pacific Studies 13, no. 1 (January 15, 2017): 95-113, https://doi.org/10.21315/ijaps2017.13.1.5. Aslan, Hifza, and Muhammad Suhardi, "DINAMIKA PENDIDIKAN ISLAM DI THAILAND PADA ABAD 19-20," Nazhruna: Jurnal Pendidikan Islam 3, no. 1 (February 7, 2020): 38-54, https://doi.org/10.31538/nzh.v3i1.476. Hifza and Aslan, "Problematika Pendidikan Islam Melayu Patani Thailand," Al-Ulum 19, no. 2 (2019): 387-401.

2 Nurfaizah, "PEMAKNAAN PAMALI DALAM MASYARAKAT SUNDA'DI DESA CIBINGBIN, KECAMATAN CIBINGBIN, KABUPATEN KUNINGAN (KAJIAN DESKRIPTIF SEMANTIK DAN SEMIOTIK)" (Masters, Universitas Pendidikan Indonesia, 2015), http://repository.upi.edu/. 
up with the pace and to respond to the challenges of the day. In fact, the culture of the past is the creation of a will based on repeated experiences that are then applied in the form of rules, provisions and disclosed in the form of advice to members of society to keep their patterns alive and well, sometimes without knowing the background. The people of the past were societies that adhered to existing restrictions because they believed there would be consequences for the violation of those restrictions.

According to Wardhaugh, taboo is certain

things are not said, not because they cannot be, but because 'people do not talk about those things'; or, if those things are talked about, they are talked about in very roundabout ways. ${ }^{3}$ Asociety that believes in taboo, believes in the consequences of violating it.

Impressions in Islamic Religion are discussed in many perspectives, such as teaching Islam to its people to do good and to avoid bad behavior. It's all learned in Moral Sciences. Bad behavior is an obstacle to be avoided in order to avoid the negative impact of the behavior.

The concept of taboos in Banjar Culture is like two sides of a currency, inseparable but inseparable. On the one hand, the taboo contains unlucky ones, which are feared if they do, so their advice is "don't do it". While on the other hand, taboos in Banjar Culture also have the purpose of making a fortune, so the recommendation is "Must be done".(meaning should be done).

\section{B. The Concept Of Taboo In Banjar Culture}

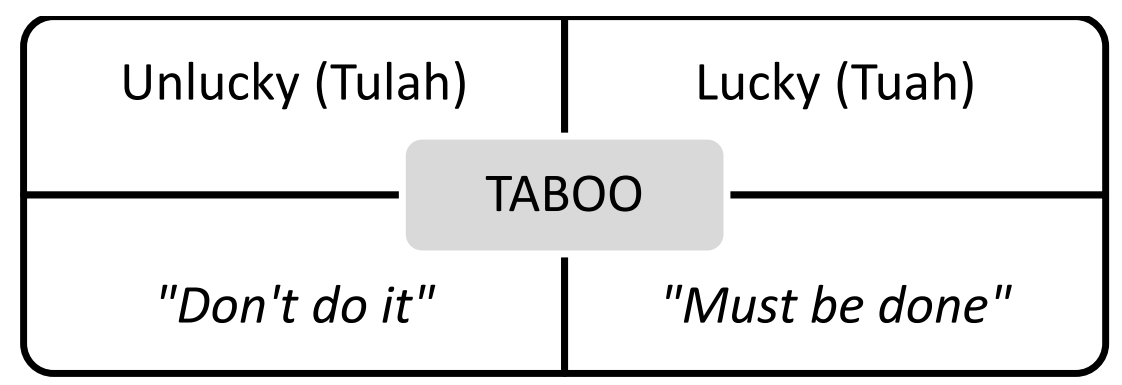

Sigmund Freud says that the meaning of the word taboo extends in two opposite directions. On one hand it means holy, holy; but, on the other hand, it is

\footnotetext{
${ }^{3}$ Ronald Wardhaugh, An Introduction to Sociolinguistics (John Wiley \& Sons, 2009).
} 
strange, dangerous, forbidden, and dirty. ${ }^{4}$ In other words taboo in the sacred and holy sense means that taboo is a prohibition aimed at members of a society to protect something sanctified or purified in order to maintain its purity. Furthermore, taboo in a strange, dangerous, forbidden and profane sense means that taboo is a prohibition aimed at members of a society against any act, word, or physical act that is prohibited by their ancestors who have their own meanings to society. This prohibition if violated will result in filth and contamination as it has tainted the sanctified sanctity.

Stories that are sometimes seasoned with myths with various restrictions must be met with caution. In Islam, not all religious explanations have to be rational, sometimes there are supernatural things that must be believed and accepted as far as religious doctrine is concerned. Behind the story of shahih (true) in Islam there is always a lesson (wisdom) that can be quoted as a lesson. ${ }^{5}$ (This (lesson Hebrew) is interesting to study in the context of Islamic culture.

The word that is identical to tabu in Banjar is called pamali. Some people think of pilgrimage as one form of superstition. Although James Dananjaja does not agree with the term because it has a lowly connotation, for him the term folk belief is more aptly used to describe it. ${ }^{6}$ Folklore (folklore) has its own tradition. Oral tradition is characterized by: a) verbal, verbal, b) non-verbal, c) belonging to the collective, d) having a fundamental meaning, transmitted from generation to generation. ${ }^{7}$

Banjar Culture is a very unique and interesting culture. There are some interesting attitudes and thoughts around the taboo issues that are developing in society. The tradition of taboos transmitted from generation to generation gives a

${ }^{4}$ Sigmund Freud, Totem and Taboo Resemblances Between the Psychic Lives of Savages and Neurotics, trans. A. A. (Abraham Arden) Brill, 2012, http://www.gutenberg.org/ebooks/41214. lihat juga, Daniel L. Pals, Seven Theories of Religion (Oxford University Press, 1996). Aslan, "Pergeseran Nilai Di Masyarakat Perbatasan (Studi Tentang Pendidikan Dan Perubahan Sosial Di Desa Temajuk Kalimantan Barat)," Disertasi dipublikasikan (Pasca Sarjana, January 17, 2019), https://idr.uin-antasari.ac.id/10997/. Aslan et al., "Dinamika Keagamaan Masyarakat Perbatasan Paloh Kabupaten Sambas, Kalimantan Barat," Jurnal Antropologi: Isu-Isu Sosial Budaya 22, no. 1 (May 31, 2020): 90-101, https://doi.org/10.25077/jantro.v22.n1.p90-101.2020.

${ }^{5}$ Muhammad bin Abdul Wahab Hamid, Stories and Myths (Bibliography Alba, 2013).

${ }^{6}$ James Danandjaja, Folklor Indonesia: ilmu gosip, dongeng dan lain-lain (Jakarta: Penerbit PT Grafiti, 1991).

${ }^{7}$ Suwardi Endraswara, Metodologi Penelitian Folklor (Jakarta: Media Pressindo, 2009). 
powerful effect as it is repeated and absorbed into the subconscious. Exchange of confidence in the values(value)based on the folklore that has developed in the community Banjar coloring rule in the rules(norms)of social and cultural life and in turn will form a cultural system that is sustainable and continues dynamics with the times.

\section{Taboo Perspective In Banjar Culture And Qur'ani Norms}

The long history of local religious and cultural acculturation in Indonesia leads to the same thing that acculturation with a decent and gentle process will be more acceptable and will naturally process. ${ }^{8}$ The same is true of Banjar culture which welcomes the arrival of Islam peacefully. There are different sides, but more in common.

In analyzing several taboo cases in different regions, namely: Banjarmasin, Martapura and Amuntai, the authors find that there are some similarities and some differences. In general they all know the term superstition in Banjar culture, they also agree that it is taboo to do bad (unrighteous) acts against parents, teachers and husbands, as it will lead to disasters that will result in disaster. But in the details that explain the attitude of the Banjar people are diverse, there are pros and cons, each with their own opinions and opinions.

In the book Pamali Banjar, it is mentioned that there are 12 different forms of monument Banjar. ${ }^{9}$ If the author is aware of the findings in three regions (Banjarmasin, Martapura and Amuntai) there are specificities in each area, but there are variations. In order to make it easier to understand taboo cases in a variety of cases, it is important to understand that tabu (pali) is a series of causes and consequences. Because it can be a word or deed, and it could be a result of efforts to avoid the plague (bad luck) or to get the luck (luck). Because in the perspective of a racist sometimes it is rational, but there are some absurdities (no logical causal relationship). As for the effects they cause are sometimes effective (successful), proven and in fact. But sometimes, the consequences can be just a myth that has no evidence. The experiences of each of the authors found in these

${ }^{8}$ Asma Luthfie et al., "Agama dan Budaya Lokal di Indonesia," AIFIS: The American Institute for Indonesian Studies, 2015, 45.

9 Yuliati Puspita Sari and dkk, Pamali Banjar (Banjarmasin: Departemen Pendidikan Nasional, 2006). 
three areas are very different, some have experienced it directly, some have just heard the story from word to mouth.

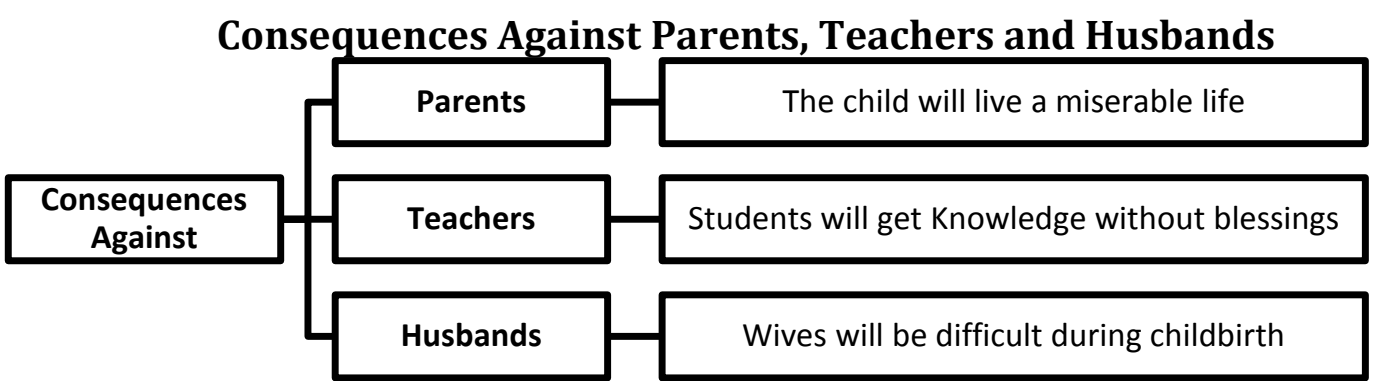

People's stories of the damned children being spread all over Indonesia. Some of them include the legend of "Sampuraga" in North Sumatra, the legend of "Si Lancang" and "Batang Tuaka" in Riau, "Putmaraga" in South Borneo. In the legend, Sampuraga is cursed into a pond, Si Lancang is cursed for a lake, Tuaka is cursed for an eagle, and Putmaraga is cursed for a dead bird. Even in Padang, West Sumatra there is the legend of "Malin Kundang" which his mother condemned to stone. ${ }^{10}$ That's how parents are cursed. Each curse and its words are considered to be very powerful, so they need to be avoided, not to hurt their heart or even to be wicked to them.

Allah the Wise had compulsorily obliged every child to devote to his / her parents. Even the order to do good deeds to parents in the Quran came along with the order to acknowledge Allah's oneness just as was decreed in the Quran, "And your Lord has commanded you not to worship anyone other than Allah and treat the parents with benevolence. If either or both of them attain to old age in your presence, then do not say even 'Ugh!' to them and not to reproach them. And always speak to both of them submissively, observing polite manners. " (QS. Al-Isra / 17: 23), "And always lower your arms of submissiveness and humility out of softheartedness for both of them and keep supplicating (Allah): 'O my Lord, have mercy on both of them as they brought me up in (my) childhood (with mercy and clemency) "(QS. al-Isra / 17: 24).

And it also had been stated in the Quran about the superiority in devotion to parents. And Allah Ta'ala said: "And worship Allah and do not set up any

10 Ronidin Ronidin, "MALIN KUNDANG, IBUNYA DURHAKA: Suatu Pendekatan Genetik," Lingua Didaktika: Jurnal Bahasa Dan Pembelajaran Bahasa 4, no. 2 (July 1, 2011): 114-25, https://doi.org/10.24036/ld.v4i2.1262. 
partners with Him. And treat the parents with moral excellence.... " (QS. An-Nisa / 4: 36). In this verse, the order to devote to parents came along with the most prominent deed, namely acknowledging the oneness of Allah, then it shows that this deed is the most prominent deed in the eyes of Allah 'Azza wa Jalla. The greatness of parents' dignity is seen by the view of Syariat (Islamic law). The Prophet considered the devotion to parents as the most important thing over Jihad fisabilillah (engage in struggle to defend the religion of Allah for His cause).

Ibn Mas'ud said: "I asked the Prophet 'Which deed is loved most by Allah?" He replied, 'To offer prayers at their early (very first) stated times.', I asked, "What is the next (in goodness)?" The Prophet (PBUH) said, "To be good and dutiful to one's parents," I asked, "What is the next (in goodness)?" The Prophet (PBUH) said, To participate in Jihad for Allah's Cause." (Sahih al-Bukhari 5970).

The hadith shows the greatness in devoting to parents; it even prevails over Jihad fi sabilillah while Jihad actually has a great superiority as well. Make your parents cry counts as one of insubordinate deeds. Their tears mean their heart is broken by the deeds of their children. Ibn 'Umar emphasized: "Tears of parents is a great insubordination." (Shahih Al Bukhari, Adabul Mufrod page 31). And Allah emphasizes in Surah Al Isra that the word "ugh" or "Ah" to parents is forbidden, especially those which are more than that. In the verse is also explained to have good deeds to parents.

Now we all have known what the importance and superiority of devoting to parents. Therefore, let's immediately say your apology to our both parents, because the pleasure of Allah depends on the pleasure of both parents. In Islam, the position of parents is so decisive that in fact, they are considered as the "personification" of the Almighty Allah.

The reflection of obedience to both parents is an indication of one's success in achieving happiness in the world and the hereafter. A person's success depends largely on the prayers and blessings of both parents. All of this is derived from the maximum effort to make the parents happy, thus inviting mercy and blessings from Allah Almighty. And in Islamic education, mothers are the first school for their children (madrasah al-ūlā). From their mothers, world leaders were born 
with their upbringing and dedication. So great is the role of a mother that the Messenger of Allah has repeated three times to serve the mother, then the father.

On the other hand, abusive behavior and treatment of the elderly will bring suffering and misery at least to the test of life (slander), as in the case of Al-Qamah (in the time of the Prophet's companions) and Juraij (in the days before the Prophet). Of course, this lesson is dedicated to children as the next generation to appreciate all the hard work of parents. Parents, meanwhile, should wish and pray for the best for their child and keep their words and attitudes free from the harm of their own children.

The next behavior that can be categorized as a breaker is through a window. If this was done, it would result in the house being destroyed. Another behavior that can lead to anxiety is sitting in the doorway. Among the things that many unmarried girls (virgins) fear is late marriage. And for those who are married, what they are worried about is difficult during childbirth. By using late reasons to marry a girl and giving birth to a married couple not to sit in the doorway, the effect of such a ban would be extremely devastating given the psychological condition of the girl. By simple logic, the purpose of the ban is not to obstruct the passageway, because sitting in the doorway will obstruct the passage of many people. The good intentions will be more effective with the consequences (if they are not followed).

In the concept of education, it is advisable that such restrictions be expressed in clear language and with rational arguments, so that they do not lead to misconceptions. But culture has its own language, indirect disclosure is considered more subtle and effective.

The consequences of late marriage can vary. Late men are the term Banjar which means late marriage to women. Causes can be various, such as: economic considerations, still studies, or because of a career (usually the beginning of a contract for a temporary marriage).

Avoiding marriage for such rational reasons is still perfectly acceptable, but when it comes to "marriages", there are a number of mystics to avoid. The bathing bath (too dusk until dusk), sitting on the door and crouching (wearing) the top (sheath) from top to bottom are considered to be the cause of late men. 
When analyzed by the concept of education, then all activities (jobs) must be in line with therole of the game. The morning and evening baths are good, but the solitude (the downstairs) is bad. Sitting is normal and natural, but in the wrong place (at the door) it's bad. Wearing a sheath, ideally from the bottom up, just like the buttons shirt, is basically from the bottom up to smooth. Everything will go well and smoothly if it conforms to its rules and provisions (proportionally).

The difficulty of giving birth according to the perception of the Banjar people can be attributed to their upbringing. Bulo because ketulahan with men,in practice as sitting in front of the door (the door), or in practice because let combs on the head. Especially for ketulahan with men,there Isarahhis wife asked the husband to be bypassed when lying down. This is considered a symbol of wife's apology. For a more detailed description of some of the cases (multi-case) previously described, please see the following matrix:

Taboo In Banjar Culture

\begin{tabular}{|l|l|}
\hline TABOO (PAMALI) & CONSEQUENCES \\
\hline Don't be againt to parents. & life becomes difficult (miserable). \\
\hline Don't be againt to your teacher. & science is not a blessing. \\
\hline Don't be againt to your husband. & It's difficult to give birth (to give birth). \\
\hline Do not enter the house through the window & Home to the thief \\
\hline Do not sit in the doorway (doo & Slowlymarried \\
& Difficult to give birth. \\
\hline Opposition to male (wrong with husband) & \\
\cline { 1 - 1 } Sitting in front of the door (the door) & Difficult childbirth (maternity) \\
\cline { 1 - 1 } Allowing comb in the head while pregnant & \\
\cline { 1 - 1 } Don't bathroom too dusk until dusk & \multirow{2}{*}{ Late to marry } \\
\cline { 1 - 2 } Ø Don't Sitting in front of the door & \\
\hline
\end{tabular}




\section{Educational Values In The Culture Of Pamali Banjar According To Islam}

In the concept of Islamic education, inviting people to the path of good and truth according to religion should be with good wisdom (wisdom) and mauizhah (advice). And if it is necessary toit must be donelegal argue (argue), thenin a good, polite andway. The concept of teaching with wisdom (wisdom) requires special expertise in dealing with diverse learners. Reason and wisdom are essential in order to organize a good and progressive Islamic education. Allah Almighty says in QS An-Nahl / 16: 125.

Call unto the way of thy Lord with wisdom and fair exhortation, and reason with them in the better way. Lo! Your Lord is the Best of theware of him who strayeth from His way, and He is the Best of theware of those who go aright.

Philosophically and theoretically, Islamic education still requires educational ijtihad. Scientific thinking on the fundamentals, principles and principles of Islamic education needs to be interpreted to be more realistic. Understanding the basic concepts of education in various aspects will further enrich the treasures of Islamic education. Of course innovation and creativity in developing Islamic education is indispensable. ${ }^{11}$ Ijtihad in today's global education world is extremely urgent to keep up to date universally and integrally, including in understanding and understanding the various values and beliefs that are developing in society.

According to Redcliffe-Brown ritual theory, rituals, magic and taboo are essentially symbolic and expressive that are often regarded as insturmental and socially responsible for social relations. ${ }^{12}$ According to this theory there is a reciprocal relationship between something of a magical nature and the social condition of society. The values and beliefs held by the community will be reflected in the social life of the community and become cultural.

The values of belief and belief in Allah swt are fundamental to Islamic teaching. It contains universal and very basic high values which in turn will

\footnotetext{
11 Kamrani Buseri, Dasar, Asas Dan Prinsip Pendidikan Islam (Banjarmasin: IAIN Antasari, 2014). Aslan and Agus Setiawan, "INTERNALIZATION OF VALUE EDUCATION IN TEMAJUK-MELANO MALAYSIA BORDER SCHOOL," Edukasia : Jurnal Penelitian Pendidikan Islam 14, no. 2 (December 10, 2019): 419-36, https://doi.org/10.21043/edukasia.v14i2.6031.

12 Akbar S. Ahmed, Toward Islamic Anthropology: Definition, Dogma, and Directions (International Institute of Islamic Thought (IIIT), 1986).
} 
produce good manners and manners in the relationship between man and his creator and between man and every creature he creates. Therefore, the values of belief in Allah swt can serve as the basis for human life in this world.

As a result of the strong belief in the existence of Allah Almighty, the attitude and behavior of believers will always be well controlled. All orders will be carried out to the best of our ability and all forms of prohibition will be avoided. Forms of prohibition sometimes come with something taboo to work with.

Religious teaching and belief recognizes several types of words that contain "strength," such as swearing, cursing, and prayer just like spells. Curse and prayer depend on God to ensure his success. The contempt of the elderly or the older, or the poor, is treated unfairly (terribly), which may speak out against the curse, and if the misfortune then overtakes others who have acted badly towards it, it is a guarantee that God has made those words prevail.

Taboo in short-sighted myths seems irrational, because it implies that people are afraid of the divine (supernatural). This means that the world is not only religious but also transcendent. ${ }^{13}$ Every real one must be supernatural, every physical one must be metaphysical, and so on.

In Islam many stories are told about mystical past stories. According to Arkoun, the mystical stories are anthropological concepts (religious, social and cultural anthropology), which will change over time. In the story are told stories of the good and the bad. The use of these symbols to convey the message of the truth of the religious language with the frame of the story. ${ }^{14}$ The moral message conveyed through the media is easy to hear and well received without any repercussions, especially on what is considered a sensitive issue.

An illustration of the prohibition in Islam is stated in the Quran, the story of Adam as. Everything is allowed to be eaten, There is only one tree that is cut down to be avoided, let alone eaten, which is the prohibition of the first human (Adam), the story of forbidden tree (shahdiah) (QS. Al-Baqarah [2 ]: 35). The consequence of this violation of the prohibition was the descent of the Prophet Adam to the

13 Sindhunata, Dilema Usaha Manusia Rasional: Kritik Masyarakat Modern oleh Max Horkheimer dalam Rangka Sekolah Frankfurt (Jakarta: Gramedia, 1982).

${ }^{14}$ Baedhowi, Anthropology of the Qur'an (Yogyakarta: PT. LkiS Excellent Printing, 2009). 
earth (QS. Al-Baqarah [2]: 36). This is considered a sanction for the offense committed. Adam repented and his repentance was accepted by Allah Almighty (QS. Al-Baqarah [2]: 37).

In Banjar culture, there is a ban on whistling at night, as they say they will invite the evil creatures who will do evil. When revised by Al-Qurtubi's explanation of Ibn Abbas which states: "The Quraysh people of the Quraysh perform the tawaf in the Sacred Mosque by naked, clapping and whistling. In their view, it is worship" (QS. Al-Anfal [8]: 35) . There is, of course, a prohibition on whistling in the Banjar Culture even in different contexts (with sanctions sometimes considered irrational).

Besides, the Apostle saw. once gave some musings for a Muslim to abandon, such as: eating with his left hand, blocking the road, the like. In Banjar culture there is no use of the left hand, whether giving or receiving. Even if you are forced to be dirty for example, then there is an apology. Contrary to the saying of the Messenger of Allah (may peace be upon him), from Umar RA, the Messenger of Allah (may peace be upon him) said: "When one of you eats he should eat with his right hand and he should drink with his right hand, for the devil is eating with his left hand and drinking with his left hand. " (HR. Muslim).

Also sitting at the door is Pamali. The admonition is in line with the hadith of the Prophet, narrated by Abu Said al-Khudri, the Messenger of Allah (may peace be upon him) said: "Keep yourself safe from the ways of life." The Companions asked: "O Messenger of Allah, that is only part of our seat, in where we used to talk there." The Messenger of Allah (may peace be upon him) said: "If you refuse (this advice), then make way for the right." The Messenger of Allah (may peace be upon him) said: "Be submissive, do not interfere, respond to greetings, call for good, and forbid evil." (Muttafaq 'Alaih).

Wake up too late is also daylight, resulting in far less sustenance. The monument is based on the hadith of the Messenger of Allah, "Get up in the morning to seek your sustenance and your needs. In the morning there will be bounty and good fortune". (HR. Ath-Thabrāni \& Al-Bazzār). In another Hadith, the Messenger of Allah (may peace be upon him) said, "O Allah, bless my people in the morning (their morning)." (HR. Ahmad). 
Prohibition of going out in the evening is also a bargain. Contributing the saying to the hadith of the Prophet, from Jabir bin 'Abdillah that the Messenger of Allah (may peace be upon him) said: "When the sun is up, keep your children from going out because at that time many demons are wandering around. When the time is past, let them be, shut the doors of the house, and call upon the name of God, for the devil cannot open the doors. Shut up the bar and call on the name of Allah, close your jars and call on the name of Allah, even if you put something on it, and turn off the lights." (Mutafaq'alaih).

Do not usewords, such as: profanepunch, bounce, scoundrel and the like. This view is in line with the hadith of the Prophet Muhammad (peace be upon him) from Abu Hurairah, the Messenger of Allah. He said: "Whoever believes in Allah and the Last Day, let him speak good or (if he cannot speak good), let him keep silent" (Muttafaq 'alaih).

Some of these illustrations are a small example of the incompatibility of some (taboo) in Banjar culture with restrictions on Islamic teaching. The rational and sensible explanation of the good intentions required by such a prohibition must be based on rational arguments and reasoning so that the maturity of thinking in the culture can grow.

In Islamic view, man is entity a unique. Its uniqueness lies in itsexistence multi-dimensional, and even the beginning of its creation was directly communicated by Allah Almighty with the angels and thus became the most noble and perfect human being on this earth. Because of his perfection and glory, God has given him privileges that give man the right to excel. Among his privileges was the appointment of man as caliph on earth. Humans are thinking beings who use language as their medium; human beings are three-dimensional beings like triangles of feet, whose feet are made up of body, mind, and spirit; human beings have the motivation and the need, the human also has the flexibility of nature which is constantly changing through educational interaction. ${ }^{15}$

\footnotetext{
15 M. Slamet Yahya, "Pendidikan Islam dalam Pengembangan Potensi Manusia," INSANIA : Jurnal $\begin{array}{llllll}\text { Pemikiran } & \text { Alternatif Kependidikan 12, no. } 2 \text { (2007): }\end{array}$ https://doi.org/10.24090/insania.v12i2.248.
} 
The dynamic nature of a dynamic human being is the potential for human development to mature. The privileges of Islam in the pursuit of faith and the formation of noble character are through reason. Al-Ghazali provides the following illustrations: Start thinking of things that are concrete and easy to see, like the sky, the earth and the environment. It will thus lead to confidence in the greatness of Allah Almighty. ${ }^{16}$ Through the verses of kauniyah and kalamiyah (qauliyah) this is the potential for human intellect to grow rapidly.

The values of education in the expression of prohibition (tabu, pamali) in Banjar Culture are relevant to the Islamic concept in some respects, although criticism of the various plagues (sanctions) is sometimes considered irrational. But the moral message that we want to convey philosophically is very good.

The new paradigm for understanding taboos in Banjar Culture needs to be shaped in line with the development of the current mindset of the Banjar community that is mature enough to understand the traditional forms of heritage that have been passed down from generation to generation.

\section{E. Concluding Remarks}

The concept of taboos in Banjar Culture is like two sides of the currency, inseparable but inseparable. On the one hand, the prohibition contains a plague (misfortune) that is feared when done, so the recommendation is "don't do it". While on the other hand, taboos in Banjar Culture also have the intention of earning (fortune), so the recommendation is "do not do" (meaning do).

Theoretically, taboo in Banjar culture is a reflection of the Quran's teaching on morals in good and bad concepts. While applied in everyday practical life, the taboo culture in the Banjar community teaches many things that are in line with the teachings of the Quran, such as: devotion, order, order, empathy, sympathy, concern, sincerity in hospitality. The essence of understanding the meaning of a prohibition is to educate the individual to obey the rules (norms) that are in line with the values believed for mutual good togather.

\footnotetext{
16 Zainuddin, Seluk-beluk pendidikan dari Al-Ghazali (Jakarta: Bumi Aksara, 1991).
} 


\section{BIBLIOGRAPHY}

Ahmed, Akbar S. Toward Islamic Anthropology: Definition, Dogma, and Directions. International Institute of Islamic Thought (IIIT), 1986.

Aslan. "Pergeseran Nilai Di Masyarakat Perbatasan (Studi Tentang Pendidikan Dan Perubahan Sosial Di Desa Temajuk Kalimantan Barat)." Disertasi dipublikasikan. Pasca Sarjana, January 17, 2019. https://idr.uinantasari.ac.id/10997/.

Aslan, Hifza, and Muhammad Suhardi. "DINAMIKA PENDIDIKAN ISLAM DI THAILAND PADA ABAD 19-20." Nazhruna: Jurnal Pendidikan Islam 3, no. 1 (February 7, 2020): 38-54. https://doi.org/10.31538/nzh.v3i1.476.

Aslan, and Agus Setiawan. "INTERNALIZATION OF VALUE EDUCATION IN TEMAJUK-MELANO MALAYSIA BORDER SCHOOL." Edukasia: Jurnal Penelitian Pendidikan Islam 14, no. 2 (December 10, 2019): 419-36. https://doi.org/10.21043/edukasia.v14i2.6031.

Aslan, Suhari, Antoni, M. Ali Mauludin, and Galuh Nashrulloh Kartika Mr. "Dinamika Keagamaan Masyarakat Perbatasan Paloh Kabupaten Sambas, Kalimantan Barat.” Jurnal Antropologi: Isu-Isu Sosial Budaya 22, no. 1 (May 31, 2020): 90-101. https://doi.org/10.25077/jantro.v22.n1.p90-101.2020.

Baedhowi. Anthropology of the Qur'an. Yogyakarta: PT. LkiS Excellent Printing, 2009.

Buseri, Kamrani. Dasar, Asas Dan Prinsip Pendidikan Islam. Banjarmasin: IAIN Antasari, 2014.

Danandjaja, James. Folklor Indonesia: ilmu gosip, dongeng dan lain-lain. Jakarta: Penerbit PT Grafiti, 1991.

Endraswara, Suwardi. Metodologi Penelitian Folklor. Jakarta: Media Pressindo, 2009.

Freud, Sigmund. Totem and Taboo Resemblances Between the Psychic Lives of Savages and Neurotics. Translated by A. A. (Abraham Arden) Brill, 2012. http://www.gutenberg.org/ebooks/41214.

Hamid, Muhammad bin Abdul Wahab. Stories and Myths. Bibliography Alba, 2013.

Hifza, and Aslan. "Problematika Pendidikan Islam Melayu Patani Thailand." AlUlum 19, no. 2 (2019): 387-401.

Luthfie, Asma, Dadang A. Permana, Siti K. Widyastuti, Ahmad Rafiq, Muhammad Takbir, Inayah Rohmaniyah, Ahmad Rafiq, and Eliyyil Akbar. "Agama dan 
Budaya Lokal di Indonesia." AIFIS: The American Institute for Indonesian Studies, 2015, 45.

Nurfaizah. "PEMAKNAAN PAMALI DALAM MASYARAKAT SUNDA'DI DESA CIBINGBIN, KECAMATAN CIBINGBIN, KABUPATEN KUNINGAN (KAJIAN DESKRIPTIF SEMANTIK DAN SEMIOTIK).” Masters, Universitas Pendidikan Indonesia, 2015. http://repository.upi.edu/.

Pals, Daniel L. Seven Theories of Religion. Oxford University Press, 1996.

Ronidin, Ronidin. "MALIN KUNDANG, IBUNYA DURHAKA: Suatu Pendekatan Genetik." Lingua Didaktika: Jurnal Bahasa Dan Pembelajaran Bahasa 4, no. 2 (July 1, 2011): 114-25. https://doi.org/10.24036/ld.v4i2.1262.

Sari, Yuliati Puspita, and dkk. Pamali Banjar. Banjarmasin: Departemen Pendidikan Nasional, 2006.

Sindhunata. Dilema Usaha Manusia Rasional: Kritik Masyarakat Modern oleh Max Horkheimer dalam Rangka Sekolah Frankfurt. Jakarta: Gramedia, 1982.

Usman, Abur Hamdi, Syarul Azman Shaharuddin, International Islamic University College Selangor, Malaysia, Salman Zainal Abidin, and International Islamic University College Selangor, Malaysia. "Humanism in Islamic Education: Indonesian References." International Journal of Asia Pacific Studies 13, no. 1 (January 15, 2017): 95-113. https://doi.org/10.21315/ijaps2017.13.1.5.

Wardhaugh, Ronald. An Introduction to Sociolinguistics. John Wiley \& Sons, 2009.

Yahya, M. Slamet. "Pendidikan Islam dalam Pengembangan Potensi Manusia." INSANIA : Jurnal Pemikiran Alternatif Kependidikan 12, no. 2 (2007): 16474. https://doi.org/10.24090/insania.v12i2.248.

Zainuddin. Seluk-beluk pendidikan dari Al-Ghazali. Jakarta: Bumi Aksara, 1991. 